\title{
USING VIDEO BLOG IN TEACHING SPEAKING
}

\author{
Muhammad Jahid Marzuki \\ Universitas Negeri Makassar \\ m.jahid@gmail.com \\ Sitti Nurpahmi \\ Universitas Islam Negeri Alauddin Makassar \\ Sitti.nurpahmi@uin-alauddin.ac.id
}

DOI: https://doi.org//0.24252/elties.vlil.7422

\begin{abstract}
This article aims at finding out whether or not video blog can improve the speaking ability of the students of English Education Department of FTK UINAM in academic year 2017/2018. The researcher applied preexperimental method, with one group pretest and posttest design which employed speaking test to find out the students' speaking performance in terms of accuracy. The sample consisted of 20 students used purposive sampling technique taken from the population of the second semester students of Sulawesi Flight. The result of the data analysis indicated that there is significant difference of students' speaking performance before and after being trained through video blog. It is proved by result of statistical analysis of the level significance 0.05 with degree of freedom $(\mathrm{df})=\mathrm{N}-1=$ $20-1=19$ which indicated that t-test value of final score I speaking ability (13.309) was greater than t-table (2.093). Therefore, video blog can improve speaking performance of the students.
\end{abstract}

Key words: Video blog, Teaching, Speaking skill

\section{INTRODUCTION}

Using technology in language teaching becomes familiar to the students since the development on ICT. To fulfil the needs of the students, so it has been developed some virtual leaning, like google classroom, online learning or some android application that can be accessed using android.

Nowadays, the fact shows that this revolution era 4.0 has brought change to every area of life not only in social politics but also in educational area. Millennial generations spend almost their three fourth of their time interact with android. Therefore, students will feel bored when they are asked to learn using conventional media. Thea will be happy they learn using android. 
Aktaruzzaman, Huq Shamim, \& Clement, (2011) stated that as the process of teaching and learning became formal and systematic in the times and technologies, the need for effective methods and strategies to raise the quality of learning have been concerned with the issue of increasing the efficiency of the learning experience.

One of media that can be used as learning media is video blog. Video blog (Vlogging) has many advantages for the students. They are: (1) Vlogging can help people share ideas that might be difficult to share through text or print; (2) Vlogging can be benefic for students who are visual learners to relate and comprehend the information; (3) Using a vlog to demonstrate an idea also gives students the ability to watch and listen to the video as many times as they want; (4) Vlogging gives people the opportunity to share their ideas with a wide audience; (5) Vlogging allow the students to share ideas and demonstrate knowledge without the confidant of text; (6) Students can use vlog to make a portfolio to showcase their work over a period of time; (7) Vlogs allow students to learn information at a time and place that is convenient for them. Students may feel less of pressure when they are allowed to think about a topic and listen to a lesson as many times as needed without the pressure from a class to move on.; (8) The Use of Vlogging to Improve The Students' Speaking Skill both to upload or download videos. (Rahmawati, Harmanto, \& Indriastuti, 2018)

The previous research found that using vlog can give positive effect toward students' performance. Paramita Sari (Sari \& others, 2017) found that the use of Vlog in the Youtube Channel can motivate students and make students confident to speak English because they were given enough time to think of what they wanted to talk about and it was done in the place they found familiar. Beena Anil (Anil, 2016) found that students showed great interest and enthusiasm while using Vlog. The findings also found that that technology would motivate and encourage youngsters to learn English in a positive way. The findings also found that Vlog created an enjoyable learning atmosphere. Moreover, they felt comfortable and relaxed while using Vlog for communication. The study showed that the level of anxiety of learning the English language is reduced reasonably. The study showed that the respondents could develop their speaking skill without peer pressure. The findings of the present study revealed no significant difference among the respondents in terms of their 
attitudes towards Vlog and variables like age, educational level but there was significant difference in the level of attitude before and after the use of Vlog.

Maulidah (Maulidah, 2017) found that Technology and social media are great combination for English learning process since they provide a chance to improve students' ability in English. A lot of media can be used to facilitate it and one of them is vlog. It is the mean to increase students' speaking ability. By supporting Vlog with a sophisticated vlogging stages and a proper scoring reflection as a feedback, it is expected to improve students' speaking ability in English.

Based on the case, do the author would like to investigate the implementation of Video blog in teaching speaking.

\section{RESEARCH METHOD}

The method in this research was a pre-experimental. It aimed at describing the speaking ability of the students in learning speaking using video blog. It was consisted of one group pre-test design. Treatment was given between pre-test and post-test.

\section{T1 $\mathrm{X} \quad \mathrm{T} 2$}

Where :

$\begin{array}{ll}\text { T1 } & \text { : Pretest } \\ \mathrm{X} & : \text { Treatment } \\ \text { T2 } & : \text { Posttest }\end{array}$

(Gay, $2016: 282$ )

There were two variables in this research, namely independent and dependent variable. The independent variable was the use of video blog in teaching English speaking, and the dependent variable was the students' speaking skill.

The population of this research was the third semester students of English education Department of FTK UINAM 2017/2018. The research applied purposive sampling technique. After the researcher observed the learning and teaching process of the population during two months, the researchers choose PBI 3 as the sample, because PBI 3 had highest motivation in 
learning English but still low in speaking and highest score in English. The total number of the students were 20 students.

The instrument of this research was a speaking test, which was administrated in pretest and post-test segment. In the pretest, the students were asked to describe some topics (personal introduction, introduce their friends and explain his/her favorite place) by their own word. Speaking test was aimed to find out the students' performance in speaking English. The tape recorder will be used to record the pretest and post-test.

\section{Procedure of the research}

\section{Pretest}

In this part, the students were asked to describe some topics. All topics were showed in picture form. The topics were Public Figure (Marshanda), General Public Place (The beach) and Technology Tools (Plane). The students chose one topic that they like. It was intended to see the students' prior knowledge on speaking. Tape recorder recorded the students who talk about their experience.

\section{Treatment}

The procedures of are treatments as follows:

1) The First treatment

1. The researchers introduced the topic;

2. The researchers devided students in pair;

3. The researchers asked students to make video related to the topic for 2 minutes and it was be recorded using video blog video;

4. The researcher asked students to upload/post the vlog from their account;

5. The researcher reviewed and gave feedback for all vlog that will have been posted in front of the class and in comment's column. 


\section{Volume 1, Number 1, March 2019}

Posttest was given after doing treatment. The researcher gave the posttest to find out the value of treatment whether or not the result of the posttest would be better than the result of the pretest. The content of the posttest was the same as the pretest but using different picture.

\section{FINDINGS}

\section{The improvement of students' speaking performance in terms of accuracy}

The application of video blog in teaching speaking could improve the students' speaking accuracy in terms of acceptable pronunciation, correct grammar, and appropriate vocabulary as indicated by the significant difference between the mean scores of the pre- and post-tests as shown in table 1.

Table 1. The development of students' speaking accuracy

One-Sample Statistics

\begin{tabular}{|c|c|c|c|c|}
\hline & & Mean & $\begin{array}{c}\text { Std. } \\
\text { Deviation }\end{array}$ & $\begin{array}{c}\text { Std. Error } \\
\text { Mean }\end{array}$ \\
\hline Pretest & 20 & 3.1667 & 1.06406 & .23793 \\
\hline Posttest & 20 & 5.5833 & .63663 & .14235 \\
\hline
\end{tabular}

Table 1 shows that the students' speaking accuracy gained a significant development, which is 2.4166 .

One-Sample Test

\begin{tabular}{|c|c|c|c|c|c|c|}
\hline & \multicolumn{6}{|c|}{ Test Value $=0$} \\
\hline & \multirow[b]{2}{*}{$\mathrm{T}$} & \multirow[b]{2}{*}{$\mathrm{df}$} & \multirow{2}{*}{$\begin{array}{l}\text { Sig. (2- } \\
\text { tailed) }\end{array}$} & \multirow{2}{*}{$\begin{array}{c}\text { Mean } \\
\text { Difference }\end{array}$} & \multicolumn{2}{|c|}{$\begin{array}{c}\text { 95\% Confidence Interval of } \\
\text { the Difference }\end{array}$} \\
\hline & & & & & Lower & Upper \\
\hline Pretest & 13.309 & 19 & .000 & 3.16667 & 2.6687 & 3.6647 \\
\hline Posttest & 39.221 & 19 & .000 & 5.58333 & 5.2854 & 5.8813 \\
\hline
\end{tabular}


Based on the $t$ test, it can be seen that the $t$ value (13.309) is greater than the $t$ table (2.093). This result proves that the hypothesis stating there is a significant difference between the mean scores of pre-test and post-test of the students' speaking accuracy in terms of pronunciation, grammar, and vocabulary is reliable.

The students' speaking accuracy developments in terms of pronunciation, grammar, and vocabulary are elaborated respectively in the following description:

\section{The Students' Pronunciation improvement}

\section{Table 2. The development of students' speaking performance in terms of pronunciation}

\begin{tabular}{l|r|r|r|r}
\multicolumn{7}{c}{ One-Sample Statistics } \\
& $\mathrm{N}$ & \multicolumn{1}{c}{ Mean } & \multicolumn{1}{c}{$\begin{array}{c}\text { Std. } \\
\text { Deviation }\end{array}$} & \multicolumn{1}{c}{ Std. Error } \\
& $\mathrm{N}$ & \multicolumn{1}{c}{ Mean } \\
\hline Pretest & 20 & 3.0000 & 1.30787 & .29245 \\
\hline Posttest & 20 & 5.8333 & .85498 & .19118 \\
\hline
\end{tabular}

Table 2 shows that the students' speaking accuracy in terms of pronunciation gained a significant development, which is 2.8333 .

\begin{tabular}{|c|c|c|c|c|c|c|}
\hline \multicolumn{7}{|c|}{$\begin{array}{l}\text { One-Sample Test } \\
\text { Test Value }=0\end{array}$} \\
\hline & \multirow[b]{2}{*}{$\mathrm{T}$} & \multirow[b]{2}{*}{ df } & \multirow{2}{*}{$\begin{array}{l}\text { Sig. (2- } \\
\text { tailed) }\end{array}$} & \multirow{2}{*}{$\begin{array}{c}\text { Mean } \\
\text { Difference }\end{array}$} & \multicolumn{2}{|c|}{$\begin{array}{l}95 \% \text { Confidence } \\
\text { Interval of the } \\
\text { Difference }\end{array}$} \\
\hline & & & & & Lower & Upper \\
\hline Pretest & 10.258 & 19 & .000 & 3.00000 & 2.3879 & 3.6121 \\
\hline Posttest & 30.512 & 19 & .000 & 5.83333 & 5.4332 & 6.2335 \\
\hline
\end{tabular}

It can be seen that the $t$ value (10.258) is greater than the $t$ table (2.093). This result proves that the hypothesis stating there is a significant difference between the mean scores of pre-test and post-test of the students' speaking skill in terms of accuracy is reliable. 


\section{The Students' Grammar Improvement}

The students' grammar was significantly developed through the use of video vlog. It is shown by the significant difference between the mean scores of their pre-test and post-test as shown in table 3.

Table 3. The development of students' speaking performance in terms of Grammar

One-Sample Statistics

\begin{tabular}{|c|c|c|c|c|}
\hline & $\mathrm{N}$ & Mean & $\begin{array}{c}\text { Std. } \\
\text { Deviation }\end{array}$ & $\begin{array}{c}\text { Std. Error } \\
\text { Mean }\end{array}$ \\
\hline Pretest & 20 & 3.9167 & 1.73332 & .38758 \\
\hline Posttest & 20 & 5.6667 & 99707 & .22295 \\
\hline
\end{tabular}

Table 3 shows that the students' speaking skill in terms of grammar were a significant development, which is 1.1

\section{One-Sample Test}

\begin{tabular}{|c|c|c|c|c|c|c|}
\hline & \multicolumn{6}{|c|}{ Test Value $=0$} \\
\hline & \multirow[b]{2}{*}{$\mathrm{t}$} & \multirow[b]{2}{*}{ df } & \multirow{2}{*}{$\begin{array}{l}\text { Sig. (2- } \\
\text { tailed) }\end{array}$} & \multirow{2}{*}{$\begin{array}{c}\text { Mean } \\
\text { Difference }\end{array}$} & \multicolumn{2}{|c|}{$\begin{array}{c}95 \% \text { Confidence Interval of } \\
\text { the Difference }\end{array}$} \\
\hline & & & & & Lower & Upper \\
\hline Pretest & 10.105 & 19 & .000 & 3.91667 & 3.1054 & 4.7279 \\
\hline Posttest & 25.417 & 19 & .000 & 5.66667 & 5.2000 & 6.1333 \\
\hline
\end{tabular}

Hypothesis testing :

$$
\begin{aligned}
& \alpha=0.05 \\
& \mathrm{t}=4.824 \\
& \mathrm{df}=\mathrm{n}-1=19
\end{aligned}
$$

Critical value of $\mathrm{t}=2.093$ 
The $t$ value (4.824) of the students' grammar is greater than the table (2.093). It is proved by the significant difference between the mean scores of pre-test and post-test. And it means that the hypothesis is reliable.

\section{The Students' Vocabulary Improvement}

The students' word choice gained developments through the use of video blog. It is shown by the significant difference between the mean scores of their pre-test and post-test as shown in table 4 .

Table 4. The Students' Vocabulary Development

\begin{tabular}{lr|r|r|r}
\multicolumn{7}{c}{ One-Sample Statistics } \\
& $\mathrm{N}$ & Mean & \multicolumn{1}{c}{$\begin{array}{c}\text { Std. } \\
\text { Deviation }\end{array}$} & \multicolumn{1}{c}{ Std. Error } \\
& & & Mean \\
\hline Pretest & 20 & 2.5833 & 1.47840 & .33058 \\
\hline Posttest & 20 & 5.2500 & 1.24193 & .27770 \\
\hline
\end{tabular}

Table 4 shows that the students' speaking skill in terms of word choice gained a significant development, which is 2.1 .

\section{One-Sample Test}

\begin{tabular}{|c|c|c|c|c|c|c|}
\hline & \multicolumn{6}{|c|}{ Test Value $=0$} \\
\hline & \multirow[b]{2}{*}{$\mathrm{T}$} & \multirow[b]{2}{*}{ df } & \multirow{2}{*}{$\begin{array}{l}\text { Sig. (2- } \\
\text { tailed) }\end{array}$} & \multirow{2}{*}{$\begin{array}{c}\text { Mean } \\
\text { Difference }\end{array}$} & \multicolumn{2}{|c|}{$\begin{array}{l}\text { 95\% Confidence Interval of } \\
\text { the Difference }\end{array}$} \\
\hline & & & & & Lower & Upper \\
\hline Pretest & 7.815 & 19 & .000 & 2.58333 & 1.8914 & 3.2752 \\
\hline Posttest & 18.905 & 19 & .000 & 5.25000 & 4.6688 & 5.8312 \\
\hline
\end{tabular}

The $t$ value (7.815) of the students' word choice is greater than the $t$ table (2.093). It proves that there is a significant difference between the mean scores of pre-test and post-test. And it means that the hypothesis is reliable. 
Volume 1, Number 1, March 2019

Based on the finding, it shows that the students' speaking skill improve in all terms-accuracy, pronunciation, grammar, and vocabulary. The findings show that the students' speaking skill in terms of pronunciation gained a significant development, which is 2.8333. it means that video blog can improve the speaking skill in terms of pronunciation. While in terms of grammar, the finding shows that shows that the students' speaking skill in terms of grammar were a significant development, which is 1.1. In term shows that the students' speaking skill in terms of word choice gained a significant development, which is 2.1.

This findings support the precious findings which have done by Maulidah (2017), Beena Anil ( 2016), and Paramita Sari (2017).

The previous research found that using vlog can give positive effect toward students' performance. Paramita Sari (Sari \& others, 2017) found that the use of Vlog in the Youtube Channel improved students' motivation and confidence. The data also suggested that students were most motivated and confident to speak English because they were given enough time to think of what they wanted to talk about and it was done in the place they found familiar. Therefore, teachers are suggested to bring technology into the classrooms more often and adjust it to the situation where students find it convenient to speak up.

According to Paramitha (Sari \& others, 2017) the use of Vlog in the Youtube Channel improved students' motivation and confidence. While according to Maulidah (2017) Vlog with a sophisticated vlogging stages and a proper scoring reflection as a feedback, it is expected to improve students' speaking ability in English. Furthermore, Beena Anil (2016) has found that using Vlog can make students have great interest and enthusiasm in learning.

Hung (Hung, 2011) found that firstly, the students favourably perceived the vlog project because vlogs not only helped them organise and reflect on their learning products, but also allowed them to archive their learning processes. Second, they reported a number of advantages associated with vlogging, such as visual representation, relief from time constraints, self-evaluation, professional development, wider audience, peer learning and technical capability. Third, in the opinion of the students, the challenges compromising the effectiveness of the vlog project involved technical difficulties, affective interferences, weak linkage to real-time communication and time issues. 
Beena Anil (Anil, 2016) found that students showed great interest and enthusiasm while using Vlog. The findings also found that that technology would motivate and encourage youngsters to learn English in a positive way. The findings also found that Vlog created an enjoyable learning atmosphere. Moreover, they felt comfortable and relaxed while using Vlog for communication. The study showed that the level of anxiety of learning the English language is reduced reasonably. The study showed that the respondents could develop their speaking skill without peer pressure. The findings of the present study revealed no significant difference among the respondents in terms of their attitudes towards Vlog and variables like age, educational level but there was significant difference in the level of attitude before and after the use of Vlog.

Maulidah (Maulidah, 2017) found that Technology and social media are great combination for English learning process since they provide a chance to improve students' ability in English. A lot of media can be used to facilitate it and one of them is vlog. It is the mean to increase students' speaking ability. By supporting Vlog with a sophisticated vlogging stages and a proper scoring reflection as a feedback, it is expected to improve students' speaking ability in English.

\section{CONCLUSION}

Based on the discussion, it was indicated that there was significant difference of students' speaking performance before and after being trained through video blog. It is proved by result of statistical analysis of the level significance 0.05 with degree of freedom $(\mathrm{df})=\mathrm{N}-1=20-1$ $=19$ which indicated that t-test value of final score I speaking ability (13.309) was greater than t-table (2.093). Therefore, video blog can improve speaking performance of the students.

\section{REFERENCE}

Abubakar, M. S. (2015). Improving the Second Year Students' Speaking Ability through Project Based Learning (PBL) at MTsN Model Makassar. ETERNAL (English, Teaching, Learning, and Research Journal), 1(2), 216-228.

Aktaruzzaman, M., Huq Shamim, R., \& Clement, C. K. (2011). Trends and Issues to integrate

ICT in Teaching Learning for the Future World of Education. International Journal of Engineering \& Technology IJET-IJENS, 11(3), 114-119. 
Volume 1, Number 1, March 2019

Anil, B. (2016). Top-Up Students Second Language Talk Time through Vlogs. Indonesian Journal of EFL and Linguistics, 1(2), 129-143.

Gay, L. R., \& Mills, G. E. (2016). Educational Research: Competencies for Analysis and Applications, Global Edition: Edition 11. Pearson Education Limited.

Maulidah, I. (2017). Vlog: the Mean to Improve Students' Speaking Ability. In International Conference on English Language Teaching (ICONELT 2017).

Rahmawati, A., Harmanto, B., \& Indriastuti, N. R. (2018). The Use of Vlogging to Improve the Students' Speaking Skill. Edupedia, 2(1), 87-95.

Rahman, I. F., \& others. (2017). Implementing Picture Dictation In Improving Speaking Ability Of The Second Year Students At Ma Pesantren Guppi Samata. ETERNAL (English, Teaching, Learning, and Research Journal), 3(2), 190-205.

Rusdi, S. Y. F. (2015). Improving the Students Speaking Ability by using thematic materials (a Classroom Action Research to The First Year Students of MTSN Model makassar). ETERNAL (English, Teaching, Learning, and Research Journal), 1(2), 257-269.

Rahmah, F., \& St Nurjannah, Y. T. (2016). The Use Of Scaffolding Talk Technique To Improve The Second Grade Students Speaking Skill AT Mts Madani Paopao Gowa. Eternal (English, Teaching, Learning, and Research Journal), 2(2), 252-268.

Syarifuddin, A. B. (2015). Grammatical Error Analisys In Thai Students'english Writing And Speaking At Uin Alauddin Makassar. Eternal (English, Teaching, Learning, and Research Journal), 1(1), 57-68.

Sari, P., \& others. (2017). Using Vlog in the Youtube Channel as a Means To Improve Students' Motivation And Confidence to Speak English in Intermediate 1 Level of LBLIA Jambi. International Journal of Language Teaching and Education, 1(1), 38-44.

Acknowledgement

The authors would like to appreciate the great thankfulness to the students of PBI 3 of FTK UINAM academic year 2017/2018 who has been samples of this research. 